\title{
III Concepts of World Literature within Publishing Practices
}

\section{III.1 From World Literature to Literatures of the World}

Now that we have examined in detail the topic of research perspectives in world literature, including the world literary concepts of writing itself, in the context of the particular characteristics of Latin American literary history, let us go on to focus on concrete examples from publishing practice. ${ }^{51}$ We shall begin with a look at the canonization processes of Caribbean literatures by globally active publishers, processes that are currently in flux; this will give us a way to examine a conceptual field of tension that will turn out to be fundamental to our work on this material. Because of its specific material situation, the Latin America program of the German publisher Suhrkamp Verlag will serve as a framework for our concrete analyses.

For this practice-oriented approach, let us now also introduce a conceptual dimension that can be summarized with the term "literatures of the world" (see Ette 2004). ${ }^{52}$ Although similar efforts have been made while retaining the term "world literature" (see for example the essays in Küpper 2013), the concept of "literatures of the world" should be seen, above all, as a programmatic modification: while the concept is certainly connected to "classical" understandings of world literature, the older term gains a completely new meaning here, a meaning that is unmistakably situated not only beyond the nation state but also beyond national literature, even though this last continues to be in possession of extremely important production, reproduction, and distribution entities. The literatures of the world have become less settled and have increasingly incorporated nomadic, moving patterns of thinking, writing, and perceiving (Ette

51 Jorge J. Locane, in his study of world literature in the Latin American context, also emphasizes the importance of the material processes of production and distribution as the sine qua non for world literature: "Thus, world literature, in which, unlike in local literatures, the chain of mediations and of added value expands exponentially, was to become the result of a complex system of connections and additions . . . . Without the mediations that are required to condition the literary artifact and offer it to that far-off reception, there is no world literature" (Así, la literatura mundial, donde, por contraste con las literaturas locales, la cadena de mediaciones y agregado de valor se dilata de modo exponencial, sería el resultado de un complejo sistema de articulaciones y sumatorias . . . . Sin las mediaciones necesarias para acondicionar el artefacto literario y ofrecerlo a esa recepción distante no hay literatura mundial; Locane 2019: 216).

52 I also address the tension between world literature and literatures of the world, with different specific focal points, in Müller (2014a, 2015a, 2015b, 2017a, 2017d, and 2018c).

Ә Open Access. ( 2021 Gesine Müller, published by De Gruyter. (c) BY-NC-ND This work is licensed under the Creative Commons Attribution-NonCommercial-NoDerivatives 4.0 International License.

https://doi.org/10.1515/9783110748383-003 
2004: 179). The following characteristics are similarly applicable to both concepts, "world literature" as well as "literatures of the world," but often have diametrically opposed focuses depending on the perspective taken:

1) Multilingualism: while the translation tally is decisive for world literature, a common characteristic of literatures of the world is that multilingualism is staged within the novels.

2) Movement: the staging of movement is always linked back to a European perspective within the concept of world literature, whereas literatures of the world stand for a dissolution of center and periphery.

3) Global/local: for proponents of world literature, the orientation towards the regional is usually intended to present a microcosm that stands in for a macrocosm, while in literatures of the world the concrete staging of regionalism often stresses the particular.

4) Non-settledness: the location of the writing is indirectly, though not necessarily, a condition for classification into one of the two concepts. Nonsettled writers are in a privileged position for being included in the canon of literatures of the world.

5) Interpretational sovereignty of Europe and the United States: both of the concepts aspire to canonize universally authoritative literatures, although a European claim to interpretation is asserted for world literature. The proponents of literatures of the world have declared this to be obsolete, and yet it is nevertheless practiced - given the actual processes of institutionalization - in the Western and Northern hemispheres.

The term "literatures of the world" has started appearing, since about the year 2000 , in the context of a variety of institutions within the literary and cultural industry that have attempted to broaden their perspectives: Berlin's House of World Cultures (Haus der Kulturen der Welt), for examples, uses the plural formation to pursue a programmatic aspiration to transmit culture and literature beyond Western hegemony; the same is true for Berlin's International Literature Festival, which has had a separate programming sector dedicated to "literatures of the world" since 2001. The Goethe Institute uses the term to recognize the special achievements of the Society for the Promotion of African, Asian and Latin American Literature in funding translations since the 1970s, using it to try to include marginalized literary works and traditions in the German book trade.

The term entered into use in academic discourse in 2002, when a conference was held in Düsseldorf with the title "World Politics - World Consciousness - Literatures of the World," co-organized by Vittoria Borsò und Ottmar Ette. But scholars have coined different phrases: while Ottmar Ette $(2004,2013)$ speaks of 
"literatures of the world," thereby pushing for a radical departure from the Eurocentrisms that are often implicit in the debate over world literature, Elke SturmTrigonakis (2007), with similar aims, uses the term "new world literature." The literary critic Sigrid Löffler, with a clear canonizing intention in alignment with these globalized times that are marked by transnational lives, uses this conceptual formation for her book Die neue Weltliteratur und ihre großen Erzähler (The new world literature and its great storytellers; 2014), where she introduces outstanding world-class storytellers to a broader, non-academic public. As announced on the website of the publisher C. H. Beck, "a completely new, non-Western literature has emerged, which is written mostly by migrants and people changing languages, from former colonies and regions in crisis. In rich and colorful language that is thoughtful and tremendously varied in tone, nomadic writers tell stories of mixed backgrounds and hybrid identities, transnational migrations and difficult integrations." 53 And although the characterization "rich and colorful" may be a well-established exoticization of literatures in Indian and Latin American contexts, for example, what is nevertheless evident here is that in the literary industry, as well, we are seeing a change in perspective in the debate over world literature.

Three dimensions of this paradigm shift seem to be particularly important:

a) the departure from Eurocentric terminology and the Eurocentric canon;

b) the focus, for canonization in the current phase of globalization, on the concrete conditions under which texts are written, taking into account the concrete processes of translation or publishing policies; and

c) a newly superimposed tendency related to content, that is to say to subject matter and to writers' biographies, in the literatures of our time on the international and transnational levels.

The term "literatures of the world" is particularly suited to capturing these dimensions because it both indicates an academic conceptualization - though one that is far from complete - and addresses a current practice in the literary business. In literary criticism and in publishing, "world literature" and "literatures of the world" are mostly used in different contexts that are clearly

53 “[Es ist eine] völlig neue, nichtwestliche Literatur entstanden, die zumeist von Migranten und Sprachwechslern aus ehemaligen Kolonien und Krisenregionen geschrieben wird. Nomadische Autoren erzählen farbig und prall, reflektiert und in den unterschiedlichsten Tönen Geschichten über gemischte Herkünfte und hybride Identitäten, transnationale Wanderungen und schwierige Integrationen" (https://www.chbeck.de/loeffler-neue-weltliteratur/product/ 12403092). 
delineated from each other: while "world literature" still implies the undeniable significance of a work and thus promotes the sales of the title or emphasizes the importance of the discussion about the author, "literatures of the world," in publishing speak, often refers more to contemporary, repositioned literatures from lesser-known areas of the world that are interesting for that very reason, and that are significant but have not yet entered the consciousness of the readers. Also understood are a greater abundance of material, greater complexity, a juxtaposition of many works and traditions, and a greater openness to incomplete or questionable selection processes.

\section{III.1.1 Caught in the Tension between Publishing Concepts: The Example of Caribbean Literatures}

After these initial reflections on the concepts of "world literature" and "literatures of the world," it is worth taking a deeper look at the literatures of the Caribbean and here, in particular, also at the literary production of the French Antilles and their international reception. ${ }^{54}$ After all, more than almost any other literary tradition, Caribbean literatures represent the interplay of deterritorialization and topographical concretization, the transcultural translation and transformation processes of epistemes and aesthetics, and the literary modelings of transterritorial linkages. ${ }^{55}$ They are thus unusually well-matched to the criteria that have been formulated for "literatures of the world." At the same time, Caribbean literatures have in the past been strongly underrepresented in what is considered to be "world literature." In this area of tension we can recognize a newly established interaction between the two concepts on the practical level of publishers' selections: while they represent two different possibilities of paradigm formation within literary theory and the cultural industry, and their criteria often have a great deal of overlap in the choice of primary literary texts, this overlap can be seen especially clearly in the international marketing and reception of Caribbean literatures. Or to put it more precisely: when the Western-dominated publishing industry chooses international literatures from regions that used to be called peripheral, the first step is the application of the concept of "literatures of the world" as a selection filter. Literary texts that have

54 See also Müller (2017a, 2017d).

55 Birgit Neumann, among others, has discussed this in our joint contribution to Vittoria Borsò's volume Weltliteratur (World literature), which is forthcoming in the series Grundbegriffe der Literaturwissenschaft (Basic concepts in literary studies), published by the Walter de Gruyter. 
successfully passed through the eye of this needle then, as a next step, become "world literature."

Examples from the English-speaking Caribbean illustrate the phenomenon of a large overlap between the two concepts: world literature from the Anglophone Caribbean that has already been canonized demonstrates the relevance of the newly formed criteria for the concept of literatures of the world, the concepts namely of non-settledness, of the staging of movement where the logics of center and periphery have been dissolved, and an emphasis on the particular, often also on the archipelago. The texts from the English-speaking Caribbean that have been canonized as world literature are apparently precisely those texts that correspond to the abovementioned change of perspective towards literatures of the world. Think for example of Derek Walcott's postcolonial 1990 epic Omeros, "in many respects . . . [a] paradigmatic work of world literature not so much because it has been translated into other languages as because of the literarily executed stories of transfer and transformation that make it into a multilayer experimental space for a divided but locally situated world consciousness" (Müller and Neumann forthcoming). ${ }^{56}$

In the context of the logics and canonization processes of world literature, it plays a crucial role if texts do not first have to be translated into English, which remains the most important language for global processes of circulation; that is why the English-speaking Caribbean occupies a special position here. Notable texts that have been successfully canonized within world literature, in addition to Walcott's Omeros, include Edward Kamau Brathwaite's The Arrivants (1967-1973), Jean Rhys's Wide Sargasso Sea (1966), V. S. Naipaul's The Enigma of Arrival (1987), and Dionne Brand's In Another Place, Not Here (1996). While literatures from the English-speaking Caribbean have thus definitely been received as world literature and at the same time can serve as guideposts for the concepts connected with literatures of the world, texts from the Spanishspeaking and especially the French-speaking Caribbean have not succeeded in attaining world literary canonization, or at any rate only in exceptional cases, of which I would like to spotlight three:

1. For the first half of the 20th century, Saint-John Perse, who was born and grew up in Guadeloupe, indisputably belongs to the canon of world literature with his poetry (Eloges 1911; Anabase 1924; Exil 1942; Vents 1946; Amers

56 "in vielerlei Hinsicht . . . [ein] paradigmatisches weltliterarisches Werk - und dies weniger wegen seiner Übersetzung in andere Sprachen als vielmehr wegen seiner literarisch vollzogenen Transfer- und Transformationsgeschichten, die es zu einem vielschichtigen Experimentierraum für ein geteiltes, aber lokal situiertes Weltbewusstsein machen.” 
1957), which is precisely oriented not towards the reality of Caribbean life but towards modern French poetry in the tradition of Arthur Rimbaud. SaintJohn Perse received the Nobel Prize in Literature in 1960.

2. The Négritude movement, with its new "Black" self-confidence, was originally shaped by French speakers and grew stronger in the 1930s; writers from the Spanish-speaking Caribbean also found their way into this movement. The Cuban writer Alejo Carpentier is of particular - and certainly world literary - importance in this context. His works can be characterized as an idiosyncratic variation of magical realism. That concept, for which Latin American writers would later become world famous, can be traced back to a formulation in the foreword of Carpentier's novel El reino de este mundo (1949; The Kingdom of this World). The selection filters that were particularly favorable for the reception of the literary quality of Carpentier's work are its ability to connect to French surrealism as well as a specific way of representing reality that stages mythical-magical practices as real and that resonated as exotic with the European public.

3. From the Cuban Revolution in 1959 through the late 1970s, Cuban literatures as a whole functioned as a model that definitely enjoyed a reception on the level of world literature and was also affirmed within the landscape of European and United States reception by leading publishers with intellectual aspirations. This is connected to the 1960s Boom in Latin American literatures, as discussed in section II.1. As a brief example from Cuba, let us mention Guillermo Cabrera Infante, whose literary influence developed through a political (albeit anti-Cuban) dimension as well as through the ability of his work to connect with the experimental writing processes that had been shaped, primarily, in the French New Novel movement.

While the reception enjoyed by the above-mentioned authors took place primarily in the context of a rather specialized readership and the authors' ability to connect with European and especially French traditions, there was a group of French-speaking writers that famously established itself worldwide beginning in the early 1990s and that produced not only literary texts but also a philosophically motivated essayistic oeuvre nourished by the context of the Caribbean experience. The concern of the writers surrounding Patrick Chamoiseau and Raphaël Confiant, from Martinique, can be read as a variation of the conceptual implications of multilingualism in literary texts, as noted at the beginning of this chapter as a characteristic of literatures of the world: with their re-valuing of oral Creole traditions, they link the act of rebellion against cultural assimilation, which represents an important element of the literary debate in the Antilles, to the level of aesthetics rather than of 
content. The success of this literary language may have consequences for standard French, because texts in French that is permeated with oral Creole have increasingly - by way of the important literary prizes and at the very latest since the award of the 1992 Prix Goncourt to Patrick Chamoiseau for his novel Texaco - entered into a French literary canon that is reshaping itself and which, in its traditional form, formed the basis for standard written French. The year 1992, in which the prestigious Prix Goncourt was once again awarded, after a gap of more than seventy years, to a writer from the Antilles, was definitely a turning point. The last time had been 1921, when René Maran won that prize for his novel Batouala, and that was an event that went down in history as the first time that an author considered "Black" won a well-known French literary prize. After a long hiatus that was not commensurate with the literary production in the Antilles, then, Patrick Chamoiseau won the prize in 1992 for Texaco, a novel that can be considered paradigmatic for the concept of literatures of the world: the text begins at the edge of Fort-de-France, Martinique's capital, where a suburb made of improvised apartments has grown up on the former compound of the Texaco oil company, an illegal neighborhood that is now to be bulldozed. What gives the novel its energy are the voices of a multitude of characters who bring the colonial history of Martinique to life, depicting the intertwining of the country's African, European, and Asian influences. There has not been a Prix Goncourt awarded to a Caribbean writer since then, but in 2009 the Prix Médicis was awarded to Dany Laferrière, who had relocated to Montreal, for his L'énigme $d u$ retour (The Return), which was again a key moment for Caribbean literary production and its international recognition. The text takes an external viewpoint, telling the story of a family between Haiti and Canada in which the protagonist, a Haitian novelist in exile, returns to Haiti for his father's funeral.

Awards like this continue to be the exception rather than the rule. We can, however, observe that the publisher Gallimard, which first published Édouard Glissant, Raphaël Confiant, and Patrick Chamoiseau, is increasingly representing writers from the French-speaking Caribbean, after a long period in which Antillean literature was dominated by Cuban writers, such as Alejo Carpentier, already mentioned as a bright light. The initial spark for this new turn could be seen as the often-cited manifesto Pour une littérature-monde (For a world literature), published by Gallimard in 2007, to which numerous well-known writers such as Maryse Condé, Édouard Glissant, Fabienne Kanor, and Dany Laferrière contributed, a manifesto that spoke out resolutely against the logic of center and periphery embedded in the concept of La Francophonie. Another crucial point is that these Gallimard writers from the French-speaking Caribbean very strongly represent the criteria for literatures of the world. 
Thus, while Caribbean literatures can have privileged access to the designation of literatures of the world, we can also see, from this brief look at the situation at Gallimard, and possibly also far beyond that, an increasingly established interplay between the world literary criterion of the translation tally and "literatures of the world" on the level of canonization by the publishers: what has already been true for literatures of the English-speaking Caribbean, namely that the criterion of "literatures of the world" is becoming more and more important for the publishing industry in choosing Caribbean writers, can now also be observed in the French book trade. ${ }^{57}$ Literary texts that have passed through the narrow constraints of this initial selection filter then have to undergo the next step, which, for international canonization, is still primarily situated in the Western world, in this case in France. ${ }^{58}$

The example we have looked at here, that of Caribbean literatures, allows us an insight into the processes of transformation that can be observed in publishing practices with respect to areas of conceptual tension within the debate over world literature. In order to be able to pursue, on the level of concrete materials, the question of how world literature is actually made, we will now take a look at the case study of one publisher: How do a publishing program or catalogue's conceptual orientations in the question of world literature come about in the first place? To what extent can a publisher's programming agenda be determined? To what extent can selection mechanisms, especially unspoken ones, be deduced?

\section{III.2 Case Study: Latin American Literatures at the Suhrkamp Publishing House}

In the second half of the 20th century, Suhrkamp was the decisive authority in the dissemination of Latin American literatures in Germany. I chose it to use as a case study here because it is one of Europe's central globally active publishers and it is also in a unique material situation: over the course of many decades, very detailed publishing records were archived, to an unusual degree, and it is from these records that I draw for the following observations. Based on this material, it can be shown that the publishing program at Suhrkamp Verlag is

57 This observation was made in March of 2017.

58 This finding, that the increased international circulation of literatures of the world is based on concrete publishing policies, is an observation that still needs to be systematically investigated. 
based on an unspoken understanding of world literature that shapes the selection criteria for foreign-language literatures.

How, then, is the history of the reception of Latin American literatures in Germany - a history in which Suhrkamp, with its almost four hundred titles, takes the leading role - related to a particular understanding of world literature? Siegfried Unseld was the head of Suhrkamp until his death in 2002 and shaped the history of the publishing house for more than forty years; he dedicated the selection mechanisms of his international literary program to the idea expressed by the founder of the former Insel Verlag, Anton Kippenberg: world literature as a biblioteca mundi, a world library based on universal categories of quality. In the following, we shall examine to what extent this selection criterion of universality, which is an elusive idea, particularly in terms of reception theory, was also joined by the idea of the exotic. To begin with, the crucial point here is that we will trace and analyze how the concept of world literature has been negotiated against the theoretical background of a consideration of transfer processes (see Werner and Zimmermann 2002), based significantly on the previously unpublished correspondence between the publisher and its authors.

\section{III.2.1 Source Material: The Siegfried Unseld Archive at the German Literature Archive in Marbach}

In December of 2009, the full collected papers of the Suhrkamp Verlag - a publishing house that had, in George Steiner's words, created something like an international Suhrkamp culture as a world literary seal of approval - became part of the German Literature Archive in Marbach (Deutsches Literaturarchiv, DLA), thereby expanding the entire archive in Marbach by a quarter (see Bürger 2010: 20). The publishing house was planning to move from Frankfurt am Main to Berlin in 2010, and this move was the reason for the sale of the documents from the "vault" in Frankfurt - the room in the basement of the publishing house in Frankfurt where business documents and correspondence with authors was stored (Cammann 2010). There was talk of more than 2100 moving boxes coming from the publishing house; along with the documents from the publisher Siegfried Unseld's villa, the estate comprises more than twenty thousand document files and more than twenty-five thousand books from the Suhrkamp and Insel publishing houses, all of which were transported to Marbach. This inventory "reflects Unseld's goals, strategies, and his enormous influence even more clearly than do his essays, books, and speeches" (spiegelt Unselds Ziele, Strategien und seinen enormen Einfluss noch deutlicher wider als seine Aufsätze, Bücher und Reden; Bürger 2010: 16). 
The Siegfried Unseld estate is considered to be the most valuable purchase in the history of the DLA, whose centerpiece until then was the collection of Cotta Verlag, the publishing home of Goethe and Schiller. Since its acquisition, the Siegfried Unseld Archive (SUA) in Marbach has gradually been made accessible for research. Ulrich Raulff, the head of the DLA at that time, spoke to the press about the acquisition as a once-in-a-century stroke of luck. Because of the press's "great dedication to filing" (hohen Ablagemoral; per Raulff, cited in Cammann 2010), the archive includes not only correspondence with Suhrkamp authors such as Samuel Beckett, Jürgen Habermas, and Julio Cortázar but also internal reports and editorial assessments, minutes of editorial meetings, informative travel reports including Unseld's own reports, and the files of the advertising and licensing departments (see Bürger 2010: 17).

From a Latin American point of view, in particular, this material is extraordinarily valuable, because Suhrkamp Verlag has played such a very decisive role in the international publishing world with respect to Latin American literature. This is the first time that such comprehensive material has been available in Germany, and we can use it as a basis from which to investigate a point in time before the literary translation and publication of Latin American writers in Germany. This makes it possible to concretely examine the selection processes of German publishers with respect to Latin American literatures, for instance, to an extent that was not even remotely possible until now. Jan Bürger describes the archive and its particular value in his commentary on the DLA's acquisition of the Unseld estate, as follows:

The notes on his [Unseld's] first encounter with Octavio Paz are an example of how carefully, in his daily work, he thought not only about the present, which the revered poet favored, but also about posterity. All of the letters from the management of the publishing house were saved and systematically filed by Unseld's staff (above all the legendary Burgel Zeeh), along with all the notes and minutes. Every trip was documented in reports . . . . All of this resulted in the archive surviving with unusually few gaps. ${ }^{59}$

(Bürger 2010: 17)

Of course even in this archive, which was so carefully prepared and assembled in the publishing house over the course of decades, the level of the material coverage varies from author to author. For this study, I have taken the material

59 "Die Aufzeichnungen über seine erste Begegnung mit Octavio Paz führen exemplarisch vor, wie sorgfältig er bei seiner täglichen Arbeit nicht nur an die von dem verehrten Dichter favorisierte Gegenwart dachte, sondern auch an die Nachwelt. Alle Briefe der Verlagsleitung wurden aufgehoben und systematisch von Unselds Mitarbeiterinnen (allen voran die legendäre Burgel Zeeh) abgelegt, ebenso wie die Notizen und Protokolle. Jede Reise wurde in Berichten dokumentiert . . . . Dies alles hat dazu geführt, dass das Archiv mit ungewöhnlich wenigen Lücken überliefert ist.” 
situation into account in a detailed way; in other words, I have chosen Latin American writers for whom there is indeed material available and accessible that is informative on the question of world literature. Hence, the institional preconditions for the material basis are in place. But how do the publisher's international selection mechanisms relate to a possible idea of world literature?

\section{III.2.2 The Choice of International Literatures at Suhrkamp: Previous History with Samuel Beckett}

In the first phase of the formation of its international program, in other words between the early 1950s and the mid-1960s, in the context of a history of world literary success at Suhrkamp, Samuel Beckett comes to mind, whose work, more than that of anyone else, corresponds to the concept expressed by George Steiner in 1973 of extraterritoriality as a constitutive element of a "Suhrkamp culture.” This can be seen, for example, in a well-known passage from Beckett's Molloy (1951), in which critics often point out a "doubled voice," which can never be clearly traced back to a particular speaker, and about which even the first-person narrator is unclear (Weber 2010: 101, 110): "I had forgotten who I was (excusably) and spoken of myself as I would have of another, if I had been compelled to speak of another. Yes it sometimes happens and will sometimes happen again that I forget who I am and strut before my eyes, like a stranger" (Beckett 1955; J'avais oublié qui j'étais (il y avait de quoi) et parlé de moi comme j'aurais parlé d'un autre, s'il m'avait fallu absolument parler d'un autre. Oui, cela m'arrive et cela m'arrivera encore d'oublier qui je suis et d'évoluer devant moi à la manière d'un étranger; Beckett 1982: 55).

The Beckett case allows us to observe an example of how much publishing success depended on particular constellations in the publishing field. One need only think of Beckett's failures when he tried to publish his work before the Second World War and his success afterwards, when he finally found publishing houses that were interested in the experimental nature of his literature and met publishers such as John Calder in London, Barney Rosset (at Grove Press) in New York, or indeed Peter Suhrkamp and Siegfried Unseld at Suhrkamp in Frankfurt. ${ }^{60}$

\footnotetext{
60 The archived materials in the SUA also make it possible to draw interesting conclusions about the marketing strategies of other publishers working in the international market. In the 1930s, for example, when Beckett was still in a very precarious position, his US publisher, Prentice (Chatto \& Windus), advised him not to write like Joyce, or rather to break away from Joyce's influence. At the same time, Beckett was "sold" to the public as a student of Joyce's as a way to guarantee his connection to modern world literature (see Nixon 2011: 3).
} 
These publishing houses, all of which were established in the 1950s, wanted to promote a new aesthetic and were open to Beckett's literature, whereas the longer-established publishers continued to resist it (see Nixon 2011: 4-5).

In 1953, during a stay in Paris, Peter Suhrkamp attended the first production of Waiting for Godot (Hartel 2011: 131). That same year, he agreed with Jérôme Lindon of Éditions de Minuit, Beckett's French publisher, that Suhrkamp would receive the rights to the German translation of the play. In 1959, Theodor W. Adorno commented favorably on Suhrkamp's involvement and foresight with respect to the success of avant-garde art, saying that Suhrkamp was succeeding in selling the unsellable, creating success for those who did not strive for it, and bringing things to the public that were "difficult to make use of" (Hartel 2011: 132). And indeed, Beckett's works sparked intellectual debates throughout the whole of postwar Germany society (Huber 1991: 31).

Eckart Voigts-Virchow describes Beckett as a trans-European writer, because he transcends the boundaries of national literatures (2009: 97). Beckett research has indicated that Unseld already recognized this transcultural dimension of Beckett's work before it had been noticed in other countries or in academic contexts (Sievers 2005: 241). The radicalization of extraterritoriality in the form of an exophonic materialization on a literary level was ideally suited to Unseld, given that he made the particularity of literature as opposed to all other discourses the point of departure for his publishing activity. On June 1, 1962, Unseld wrote to Beckett:

As far as I know, you are the only important writer to have written in two languages. This fact seems to me to be worth respecting and emphasizing in an edition of your dramatic works. Therefore, I would like to publish an edition in three languages . . . . What do you think of this project? Of the project of an edition of your dramatic works, as well as of the "triglot" project? I do not yet know whether the third solution will be feasible, but before doing any more research, I would like to know your opinion ${ }^{61}$

(Letter from S. Unseld to S. Beckett dated 6/1/1962, SUA)

$\mathbf{6 1}$ "Autant que je sache, vous êtes le seul écrivain important qui ait écrit en deux langues. Ce fait me paraît digne d'être respecté et souligné dans une édition de vos œuvres dramatiques. J'aimerais donc publier une édition en trois langues . . . . Que pensez-vous de ce projet? Du projet d'une édition de vos œuvres dramatiques ainsi que du projet 'triglotte'? Je ne vois pas encore si la troisième solution sera réalisable, mais avant toute autre recherche j’aimerais savoir votre avis?"

For their kind permission to publish these quotations from the holdings of the Siegfried Unseld Archive, I very much thank the authors and their heirs, as well as the German Literature Archive in Marbach. All quotations by Siegfried Unseld are copyright (c) Suhrkamp Verlag Berlin, with all rights reserved. 
Suhrkamp was in fact the only publisher at that time that deliberately made a point of Beckett's bilingualism: the two-volume work in three languages that Unseld had suggested appeared in 1963/64 as Dramatische Dichtungen (Dramatic poems), which made Beckett feel highly appreciated (see Hartel 2011: 133-34). Unseld became a strong advocate for Beckett, although his work was very hard to market because he would give neither interviews nor public readings (Sievers 2005: 226). Unseld worked ambitiously for his author Beckett and for Beckett's international reception: after he sent for the version of the play Happy Days that Fischer Verlag wanted to produce with the Deutsche Grammophon recording label, he let Beckett know that the texts had been abridged. Beckett reacted by transferring the rights to the play to Suhrkamp, along with the rights to all further plays from 1962 (see Hartel 2011: 135). In 1969, Beckett won the Nobel Prize in Literature. The first paperback Suhrkamp ever published was Beckett's pivotal play Waiting for Godot, which appeared in 1971, also as a trilingual edition. The 15,000-copy printing sold out within a year (ibid.). Unseld also encouraged Beckett to create a film version of his play Not I and to direct it himself.

His handling of Beckett's work is an example of how extremely important Unseld was for some of his foreign-language writers. Unseld was very aware of his position as a gatekeeper (in the terms of Marling 2016) and of his role in the international success of his writers in general and of Beckett in particular, as we can see from the following excerpt from another letter he wrote to Beckett after he was awarded the Nobel Prize in 1969: “Dear Sam, I didn't write you immediately after the news, so as not to contribute to the avalanche. You know that I am very pleased with this news and you also know that I contributed quite a bit to the whole thing" (Lieber Sam, ich habe Ihnen nach der Nachricht nicht geschrieben, um die Lawine von mir aus nicht zu vergrößern. Sie wissen, daß ich mich über diese Nachricht sehr freue und Sie wissen auch, daß ich Einiges zu der ganzen Sache beigetragen habe; Letter from S. Unseld to S. Beckett, 11/06/ 1969, SUA). Beckett, in turn, confirmed his German publisher's important role very explicitly in his response (letter from S. Beckett to S. Unseld, 11/06/1969, SUA). The warm tone of the correspondence is an indication of the friendly connection between the writer and the publisher. And it was Unseld's particular involvement that would also become very valuable for a series of Latin American writers. It was not without reason that Octavio Paz wrote, in a letter dated July 31, 1980, about his first trip to Germany in June of that same year, "but our great discovery in Frankfurt was Siegfried Unseld" (aber unsere große Entdeckung in Frankfurt war Siegfried Unseld, cited in Bürger 2010: 13). Beckett's publication history at Suhrkamp displays a collection of characteristics that are also significant for the consideration of the selection of Latin American 
literatures made by the publisher. As in the case of Octavio Paz, who will be the subject of section III.2.5, Unseld maintained a very personal and even emotional relationship with Beckett as well as an intensive intellectual exchange - although, unlike with Paz, it was much more difficult in Beckett's case to connect him with other Suhrkamp authors (Rathjen 2013: 109).

In summary, we can say that even though the successes of someone like Samuel Beckett, or of a writer like Marguerite Duras, began earlier, neither French literature nor any other international literature at Suhrkamp ever experienced such a resounding reception as Latin American literature did. The expectations for extraterritoriality relinquished the imprint of linguisticphilosophical intellectualism that characterized Samuel Beckett, and what took its place was a specific place named Macondo. What might be the reason for that?

\section{III.2.3 The Latin America Program, Part I: The Success Phase, 1969-2000. Between Universalism and Exoticism}

Following Latin American literature's international Boom (see section II.1) at the end of the 1960s, Suhrkamp Verlag's Latin America program ${ }^{62}$ developed steadily. Beginning with the first edition of Vallejo in 1963, it was constantly expanded; the high point was when 17 titles were published in 1976 alone, when Latin America was the focus of the Frankfurt Book Fair, as well as when several million copies of Isabel Allende's House of the Spirits were sold in the 1980s. ${ }^{63}$ How, then, was this literature received in Germany? ${ }^{64}$ A cursory look at the reviews that appeared following the publication of Gabriel García Márquez's Cien años de soledad (Hundert Jahre Einsamkeit in German, 1967) or Mario Vargas Llosa's La casa verde (Das grüne Haus in German, 1965) quickly make it clear that the concept of world literature was the implicit yardstick. Vittoria Borsò has pointedly detailed the connection between world literature as a selection criterion and the reception by publishers. And what she notes for Hundert

62 The program category at Suhrkamp is officially called "Literature from Latin America, Spain, and Portugal," and therefore also includes titles from the Iberian Peninsula. However, the focus is clearly on Latin American literatures; the text on Suhrkamp Verlag's home page introducing this category, for example, only refers to the subcontinent (https://www.suhr kamp.de/themen/literatur_aus_lateinamerika_spanien_und_portugal_192.html). And because the focus of this study is also on Latin American literature, I refer to it as the "Latin America program."

63 As of 2002, this number was already over three million (see Heine 2002: 120).

64 In Müller (2014a, 2015a, and 2015b), I also address this phase of Suhrkamp's Latin America program, among other things. 
Jahre Einsamkeit, which was published by Kiepenheuer \& Witsch, can also be applied to Suhrkamp authors such as Vargas Llosa: the literary reviews can be summarized as emphasizing that the assimilation of European and international traditions, along with, at the same time, the integration of oral narratives from pre-Columbian cultures, are what indicate membership in the world literary canon. These writers were enriching the European and Western traditions with the lush colors of the tropical world. The paradigm of identity, and specifically the search for a specifically Latin American identity, was a decisive criterion for making the novels acceptable within world literature (Borsò 2004: 236).

According to Borsò, another feature that elevated these novels, and especially La casa verde, to the rank of world literature was the fact that what took place in the mythical Amazonian town on the Marañon River (comparable with García Márquez's Macondo) was not just the history of Latin America but also the history of the world, as represented by the abundant allusions to the Book of Genesis and to archetypal myths of origin (ibid.). In sum, we can state that the reception of these books by literary critics and literary scholars primarily paid attention to their ability to connect to modern world literature, with a particular emphasis on the combination of exoticizing representations of alterity with established European postmodern writing processes.

How do the publishing industry's opinions compare to this? The archival holdings of the Suhrkamp Publishing House, especially Siegfried Unseld's correspondence with the authors but also with his closest Latin America advisers, Michi Strausfeld and Wolfgang Eitel, provide vivid material for us here. Encounters with some leading Latin America scholars, such as Klaus Meyer-Minnemann, Dieter Janik, and Karsten Garscha, are also reflected. In May, 1979 Unseld wrote in his notebook: "Octavio Paz made a big impression on me. A personality that unites poetry and learnedness, wisdom and science. I invited Paz and also Carpentier to come to Germany for a visit" (Octavio Paz hinterließ mir einen großen Eindruck. Eine Persönlichkeit, in der sich Poesie und Gelehrsamkeit, Weisheit und Wissenschaft vereinen. Ich habe Paz und auch Carpentier zu einem Besuch nach Deutschland eingeladen; Unseld travel report, Paris, 5/20-5/22/1979, SUA). One thing was evident: anyone who belonged to the illustrious circle of non-German Suhrkamp authors had to be considered "able to be treated as belonging to world literature." The equation of the publishing program with world literature seems unquestionable. The fact that Octavio Paz fulfilled this function particularly well may also be connected with his positive understanding of a genuinely European modernity.

Unseld particularly liked to use the German classics as a measure for his selections. Thus, after a meeting with Alejo Carpentier in Paris, Unseld noted that Carpentier "spoke about his work and about the world with equal 
confidence. He is a Latin American Thomas Mann" (sprach von seinem Werk und von der Welt gleichermaßen souverän. Ein Thomas Mann Lateinamerikas; Unseld travel report, Paris, 5/20-5/22/1979, SUA). The Cuban author, in return, confirmed through his enthusiasm for Germanic literatures that the "Thomas Mann" seal of approval was a criterion for Unseld. Thus, in his travel report, Unseld continues: "That gave Carpentier the opportunity to speak at length about the Icelandic sagas, the Celtic myths, and the German heroic legends, and then I was completely astonished when he brought up Wolfram von Eschenbach's 'Parzival' as an important document” (Das gab nun Carpentier die Veranlassung, ausführlich über die isländischen Sagen, über die keltischen Sagen, über die deutschen Heldensagen zu sprechen und völlig verblüfft war ich dann, als er Wolfram von Eschenbachs "Parzival" als wichtiges Dokument hervorhob; Unseld travel report, Paris, 5/20-5/22/1979, SUA). And while in this case the modern German classic author Thomas Mann was used as a comparison, in another context Unseld made reference to contemporary leftist cultural theorists, such as Herbert Marcuse:

Octavio Paz . . . . You get the impression that the experiences of long periods of social and literary revolutions have converged in him. To me, he is an important character in our times, when the belief in progress and the belief in a historical process seem to be fading . . . . In himself, he creates variations on what Marcuse said about the "zest for life" in the Römerberg discussion series. ${ }^{65} \quad$ (Unseld travel report, Paris, 5/20-5/22/1979, SUA)

\section{III.2.4 Suhrkamp as a Producer of Leftist Theory: The Case of Darcy Ribeiro}

There is a political component that plays an essential role for the German reception of Latin American Boom authors, as it does for their worldwide reception. Not only is the Suhrkamp Verlag's Latin America program an example of this phenomenon, but the publisher also decisively helped to shape it, given that Suhrkamp is considered to have been the forge for nondogmatic leftist theory in Germany from the 1960s through the 1980s. ${ }^{66}$ The publisher's sociopolitical commitment in general, and Unseld's similar commitment in particular, as well as the role that the reception of Boom literature played within that commitment,

\footnotetext{
65 “Octavio Paz . . . . Man hat den Eindruck, in ihm seien Erfahrungen langer Zeiten von sozialen und literarischen Revolutionen zusammengeflossen. Für mich ist er in unserer Zeit, wo der Fortschrittsglaube und der Glaube an den historischen Prozeß zu verdämmern scheint, eine wichtige Persönlichkeit . . . . Er variiert für sich das, was Marcuse in den Römerberggesprächen zum Thema 'Lebenslust' ausgeführt hatte.”

66 On this topic, from a slightly different perspective, see also Müller (2014c, 2017b).
} 
is directly connected with political interest in Latin America: to a certain extent, in the 1960s and 1970s, the subcontinent became a sociopolitical laboratory, a beacon of hope for Western European, but especially German, leftists, and later, with the arrival of the military dictatorships, served to legitimize the critique of capitalism (under the terms of dependency theory). The literary interest in Latin America, following this line of thought, can then be seen as the flip side of the political interest in and commitment to a more socially just world, as well as a fictional undergirding of the theoretical critique of capitalism.

A decisive dimension of the German reception of Latin American literature can be seen here, a dimension that comes to a head in the case of a Brazilian Suhrkamp author who, though he was neither a classic bestselling author nor part of the Boom, is nevertheless and for that very reason symptomatic of the dominant patterns of reception with respect to Latin American literatures: Darcy Ribeiro. In his report on his trip to Paris from May 20th to 22nd, 1979, Unseld writes: "What about the Darcy Ribeiro complex? Will this continue in the academic field? I'm asking Mr. Herborth for news. A few days earlier, Darcy Ribeiro gave a brilliant speech while accepting his honorary doctorate from the Sorbonne" (Wie steht es mit dem Komplex Darcy Ribeiro? Geht das im wissenschaftlichen Bereich weiter? Ich bitte Herrn Herborth um Nachricht. Darcy Ribeiro hat einige Tage vorher eine blendende Rede zur Entgegennahme seines Ehrendoktors an der Sorbonne gehalten; SUA).

Unseld's implicit categories for evaluating literary quality are then also fed by this kind of academic recognition from one of the oldest and most prestigious universities in "old Europe." Ribeiro, a sociologist, scholar of cultural studies, and writer, published The Americas and Civilization with Suhrkamp in 1985 (German title Amerika und die Zivilisation), the second volume of a series of studies in cultural anthropology in which Ribeiro examined the history of the American peoples and their development perspectives, using his own specific theory of civilization. He was received in Germany as part of the generation of Latin American intellectuals who, according to the critics, established the modernity of the subcontinent by going back to its roots - its indigenous, African, and European origins. Ribeiro's novels, in particular, such as Maira and Mulo (in Brazilian Portuguese $O$ mulo), were elevated to the rank of world literature on the basis of the already existing exoticizing and universalizing selection criteria, to which in Ribeiro's case another, equally decisive, dimension was added: the political. 


\section{III.2.5 Octavio Paz: The “Model” of a Latin American World Literary Figure?}

In order to further determine what standards Unseld used as a publisher in terms of world literary relevance and the negotiability of Latin American writers, it is worthwhile to take a closer look at the example of Octavio Paz. ${ }^{67}$ On April 30, 1998, ten days after Octavio Paz's death, Siegfried Unseld wrote a letter of condolence to Paz's wife Marie-José including the following lines, which strikingly describe the two main dimensions of the relationship between Paz and Unseld:

For all of us Octavio is the great author. We are proud to have taken care of his work. And you can be sure that we will continue to work for him and his work, to have his books in print and to publish new ones, so that his ideas can continue to irradiate and illuminate the German public.

(Letter from S. Unseld to M.-J. Paz, Frankfurt am Main, 4/30/1998, SUA)

Unseld is speaking here in two modes. The first is that of the resourceful, successful businessman who took Paz into his Latin America program years earlier, with wise foresight and delicate marketing insight, and was then retroactively validated and rewarded for his faith in the Mexican author when Paz won the Cervantes Prize in 1981 and then the Nobel Prize in 1990. But the other shows us Unseld's picture of Paz - or to put it more strongly, his projection onto Paz - as a man of letters who was Latin America's 20th-century Enlightenment man and whose ideas, characterized by their progressiveness for their time, their farsightedness, their educational character, and, not least, their world literary quality, must not be allowed to vanish. The 1980s image of Paz is reflected in a statement by the former German president Richard von Weizsäcker, who gave the speech honoring the winner of the German book trade's Peace Prize in 1984: "In his own way, Octavio Paz has become the defining voice of Latin American culture, and its conscience" (Octavio Paz ist auf seinem Weg zur prägenden Stimme lateinamerikanischer Kultur geworden, zu ihrem Gewissen; cited in Suhrkamp Verlagsgeschichte 1990: 122).

Unseld's programmatic understanding of what constituted a deserving and potentially successful Suhrkamp author worth publishing in the Latin America program should be understood, in particular, against the backdrop of the Suhrkamp House's classic, established, and in particular German-language authorial poetics as well as of the 1970s and 1980s West German context of cultural

67 The following observations on Siegfried Unseld's reception of Octavio Paz can also be found, in a similar form, in an article that I wrote with Sylvester Bubel (see Müller and Bubel 2016). 
consumption by the educated middle class. When we take a closer look at Octavio Paz's poetological, existential-religious, and sociopolitical ideas and convictions, then, we can see how interesting and relevant they made him for Unseld and for Suhrkamp's Latin America program in this context. These characteristics of Paz and his work were poetological parameters that allowed him entry into the world literary guidelines that Unseld and Suhrkamp had established for the Latin America program, and that made it possible for his texts to be integrated into and functionalized for the German-speaking market. According to Unseld, Octavio Paz's work fit Suhrkamp's world literary criteria in exemplary fashion.

In his report on his meeting with Paz in May, 1979, in Paris (which was probably their first meeting), Unseld was deeply impressed by the Mexican writer's demeanor and deep knowledge. He noted: "an impressive figure, poet and scholar, wise and knowledgeable” (eine imponierende Erscheinung, Poet und Wissenschaftler, Weiser und Wissender; Unseld travel report, Paris, 5/20-5/22/1979, SUA). But what was the basis for this assessment by Unseld of Paz the intellectual and man of letters? This raises the question of whether and to what extent it is Paz's work that allows this (projectionist) perspective, or whether Unseld simply superimposed Suhrkamp's publishing categories onto Paz's person and oeuvre for pragmatic reasons to do with the politics of publishing.

So what are the substantial and formal aspects and methods with which Paz, the "wise and knowledgeable," was able to secure his status as a Latin American polymath and Enlightenment man in Unseld's perception? In order to better understand this connection, we need to undertake a short and fragmentary description of Unseld's understanding of a world-class "Enlightenment man" or "knowledgeable" figure; this can best be accomplished by looking at the implications of the comparative categories with which Unseld tried to grasp Paz within his own artistic understanding. Thus, Unseld sees the triad Cortázar/ Paz/Carpentier as the "greats of Latin American literature. All three of them impressive, because they reflect not only what is their own, their own continent, but also the others in themselves" (Großen lateinamerikanischer Literatur. Alle drei beeindruckend, weil sie nicht nur das Eigene, den eigenen Kontinent, sondern auch die anderen in sich reflektieren; Unseld travel report, Paris, 5/20-5/22/1979, SUA). Thus, Unseld categorizes Paz as a "universalist" writer who is able to go beyond his own national and ethnic limits and boundaries and address the - supposedly - higher, existential questions in his work. A "world traveler" 68 who oscillates, conceptually, between the reference points of Latin America and Europe.

68 As Michi Strausfeld put it in an internal draft, headed "es-NF-Lateinamerika," probably from 1980 (SUA). 
Behind this intellectual elevation of Paz to a nobleman of Latin American literature - alongside Julio Cortázar and Alejo Carpentier, the "Thomas Mann of Latin America” (Unseld travel report, Paris, 5/20-5/22/1979, SUA) - one could also, however, suspect a gimmick for the sake of publishing policy: with Cuba, Mexico, and Argentina all together, Unseld could unite the most politically interesting regions of Latin America into one category in his publishing program and thus make them concrete for the German postwar middle class.

Meanwhile, in addition to considerations of publishing policy and the above-mentioned Enlightenment paradigm, Unseld's reception of Paz's poetics includes a third and decisive aspect: the publisher was deeply impressed by a lecture that Paz gave in Frankfurt am Main in the summer of 1980, and the central message that Unseld took away from the Mexican writer's aesthetic and poetological considerations was this: "Yes, it's true: America Latina es una cultura - Latin America is one culture" (Ja, es ist wahr: America Latina es una cultura - Lateinamerika ist eine Kultur; letter from S. Unseld to O. Paz, 07/04/ 1980, SUA). In spite of the very great diversity with respect to politics, culture, ethnicity, language, and, finally, literature, Unseld wanted Latin America to be seen as a homogeneous whole, whose political process of individuation was not only thoughtfully accompanied, but also actively guided and propelled, by contemporary literature. And thus, Suhrkamp often promoted Latin American literature with the label "existentialist" and advertised Latin America as a kind of "untainted" emotional (continental) space still being constituted. It is no wonder, then, that in 1979 Suhrkamp's Latin America program was published under the title "17 Authors Write the Novel of the Latin American Continent" (17 Autoren schreiben am Roman des lateinamerikanischen Kontinents) or that it contained this concise comment by Unseld:

Of all the non-German contemporary literatures, it is Latin American literature that certainly seems to me to be the most important for the coming decade. It is a particular kind of existential literature, a kind that in other countries, for whatever reasons, can only be written in individual cases. This literature encourages a new education in feelings, and its very real figures are not afraid to name the values in life nor to rank them. ${ }^{69}$

(SUA)

\footnotetext{
69 "Von allen außerdeutschen zeitgenössischen Literaturen scheint mir die lateinamerikanische sicherlich für das nächste Jahrzehnt die wichtigste zu sein. Es ist eine besondere Art existentieller Literatur, wie sie in anderen Ländern, aus welchen Gründen auch immer, nur noch in einzelnen Fällen geschrieben werden kann. Diese Literatur macht Mut zu einer neuen Erziehung zu Gefühlen und ihre so realen Gestalten scheuen sich nicht, Werte des Lebens zu benennen und in ihrem Rang zu bestimmen."
} 
This kind of "existential" Latin American literature, one that was able to "name the values in life" and even kindle a new "sentimental education," still, however, followed familiar coordinates in Unseld's understanding: on the topic of Paz's poem "Piedra de sol" ("Sunstone"), ${ }^{70}$ with whose "hunger for existence" (Hunger nach Sein), as he put it, Unseld was explicitly impressed, he wrote that he was particularly fascinated by how the poem ended, the "symbol of the river 'that turns, moves on, / doubles back, and comes full circle, / forever arriving,' the soft water in motion" (Symbol des Flusses, "als der, der sich windet, verdrängt, zurückweicht, einen Umweg wandelt und immer ankommt," das weiche Wasser in Bewegung; Unseld travel report, Paris, 5/20-5/22/1979, SUA; English translation of poem fragment from Paz 1991). It does not appear to be a coincidence that it was exactly this kind of metaphors, images, and figures using the topoi of literary and philosophical history, such as the Heraclitean panta rhei, that Unseld particularly appreciated in Paz's work. If we think of the orientation of the Latin America program and its strategy of "Latin American awakening," then this metaphorics, which was steeped in history and could be interpreted in a universalist way, was necessary in order to be able to bring Latin America close enough so that the almost uninformed German-speaking audience could grasp it.

In addition, this metaphorics was what qualified the Mexican writer Paz who, because he was Mexican, still seemed exotic to German-speaking audiences of that time - to be included in the group of Suhrkamp's historically significant authors. It was Unseld's ambition, in his Library of Modern Classics (Bibliothek der Klassiker der Moderne), which has become historically significant, "not [to publish] the excavations of esoteric occasional writings but rather [to aim for] a unity in the final object that would, in spite of the highly divergent topics, justify the claim: here literature becomes an escape into life" (keine Ausgrabungen abseitiger Gelegenheitsarbeiten [zu publizieren], vielmehr trotz divergierendster Themen eine Geschlossenheit im Ziel [anzustreben], die die Behauptung rechtfertigt: Hier wird Literatur zur Flucht in das Leben; Unseld 1989). Unseld seems to understand this escape into life as specifically modernist, shaped by Friedrich Nietzsche's emphatic “yes to life" and Bergson's "vital impulse," as well as by politically engaged literature - from the Weimar Republic (including Hesse and Brecht) to its existentialist manifestations (including Sartre and Camus); and the more points of intersection with these literary greats Unseld can find in the aesthetics of the Latin Americans, the more valuable he finds their work.

70 This poem is one of Octavio Paz's major works, and Unseld can be shown to have read it. Suhrkamp published it in German in 1977, in the volume Octavio Paz. Gedichte (Octavio Paz. Poems) and again in 1979 in Suche nach einer Mitte. Die großen Gedichte (The search for a center. The great poems). 
Unseld's conviction that literature is inseparable from social engagement and sociopolitical action is demonstrated not only by the programmatic orientation of Suhrkamp's postwar "Bibliothek Suhrkamp" book series but also by the extremely positive light in which Unseld saw socially engaged writers and intellectuals (such as Darcy Ribeiro) who were not spending their time in the ivory tower of l'art pour l'art. Paz's aesthetic distinguished him from such artistic escapisms (the kind we know, for instance, from Symbolism) without making him into a mouthpiece for political or social positions. All too often, politically committed literature is unable to free itself from the teleological thought patterns of bourgeois rationality, so that it can in fact be seen as the poet's role to create a protected space, through poetry, in which supratemporal ideas and knowledge can survive unaffected by the zeitgeist, freed from any appropriation by bourgeois categories of thought. Thus, for example, Paz writes in Sor Juana Inés de la Cruz o Las trampas de la fe (Sor Juana or, the Traps of Faith):

Bourgeois rationalism is, in a manner of speaking, constitutionally averse to poetry. Hence poetry, from the beginnings of the modern era - that is, since the last years of the eighteenth century - has been a form of rebellion. Poetry is not a genre in harmony with the modern world; its innermost nature is hostile or indifferent to the dogmas of modern times, progress and the cult of the future . . . Poetry, whatever the manifest content of the poem, is always a violation of the rationalism and morality of bourgeois society. Our society believes in history: newspapers, radio, television, the now; poetry, by its very nature, is atemporal. ${ }^{71}$

(Paz 1988: 5)

Here Paz rejects the politicization, appropriation, and influence of bourgeois values on literary production and ascribes a unique rebellious power to poetry and the poet, a power that is able to produce a genuinely different epistemology: namely, a timeless, morality-generating knowledge of life, beyond positivism, rationalism, or empiricism. It is through this separate kind of literary politicization that the poet fulfills his responsibility to society, as Paz stresses in "La letra y el cetro" (The letter and the scepter): "But we cannot disavow politics; that would be worse than spitting into the sky: it would be spitting at

71 "El racionalismo burgués es, por decirlo así, constitucionalmente adverso a la poesía. De ahí que la poesía, desde los orígenes de la era moderna - o sea: desde las postrimerías del siglo XVIII - se haya manifestado como rebelión. La poesía no es género moderno; su naturaleza profunda es hostil o indiferente a los dogmas de la modernidad: el progreso y la sobrevaloración del futuro . . . . La poesía, cualquiera que sea el contenido manifiesto del poema, es siempre una transgresión de la racionalidad y la moralidad de la sociedad burguesa. Nuestra sociedad cree en la historia - periódico, radio, televisión: el ahora - y la poesía es, por naturaleza, extemporánea” (Paz 1985 [1982]: 16). 
ourselves" (Pero no podemos renegar de la política; sería peor que escupir contra el cielo: escupir contra nosotros mismos, Paz 2002 [1972]: 754-55).

What Unseld so values in Paz's work is exactly that creative, rebellious power that Paz sees in the medium of literature and especially of poetry. The attempt to establish poetry as its own separate epistemological category can be found in many of the modernist poets in the orbit of the Suhrkamp Verlag, for instance in Hugo von Hofmannsthal, who was so highly esteemed by Unseld, and whose 1906 essay "Der Dichter und diese Zeit" (The poet and this time) ${ }^{72}$ shows striking similarities to Paz's thinking:

No thought that impresses itself on him [the poet] must he chase away, as though it were from a different order of things. For every thing must fit into his order of things. In him everything must and wants to come together. It is he who in himself knits together the elements of time. The present is in him or nowhere ... . Just as the innermost sense of all people creates time and space and the world of things around them, so does he create, out of past and present, out of animal and human and dream and thing, out of large and small, out of the lofty and the trivial, the world of connections. ${ }^{73}$

(Hofmannsthal 1979 [1906]: 67-68)

For Unseld, Hofmannsthal certainly represented one of the most important European tertia comparationis with which to evaluate Paz's oeuvre. A letter from Unseld to Paz dated July 4, 1980, for example, in which Unseld reminisces about a weeklong visit that Paz and his wife Marie-José had made to Germany, testifies to the publisher's urge to position Paz within the tradition of established Suhrkamp authors and German-speaking intellectual greats. During the trip through West Germany (Bonn, Frankfurt, Heidelberg), not only is it "obvious" that a visit to the Goethe house should be included, but in the Goethe library, they also had to be shown "Hofmannsthal treasures," because according to Unseld, Hofmannsthal "was after all one of the few German poets who knew Spanish" (war ja einer der wenigen deutschen Dichter, die des Spanischen mächtig waren, letter from S. Unseld to O. Paz, 07/04/1980, SUA). Against the background of these comparisons with Hofmannsthal, the following

72 This essay consists of a lecture that Hugo von Hofmannsthal gave several times at the end of 1906. "Der Dichter und diese Zeit" was first published in March of 1907 in Berlin, in the Neue Rundschau.

73 "Keinen Gedanken der sich an ihn drängt, darf er von sich scheuchen, als sei er aus einer anderen Ordnung der Dinge. Denn in seine Ordnung der Dinge muß jedes Ding hineinpassen. In ihm muß und will alles zusammenkommen. Er ist es, der in sich die Elemente der Zeit verknüpft. In ihm oder nirgends ist Gegenwart. . . . . Wie der innerste Sinn aller Menschen Zeit und Raum und die Welt der Dinge um sie her schafft, so schafft er aus Vergangenheit und Gegenwart, aus Tier und Mensch und Traum und Ding, aus Groß und Klein, aus Erhabenem und Nichtigem, die Welt der Bezüge.” 
quotation from Unseld's 1979 travel report, from which I have already cited, becomes all the more significant:

In our time, where the belief in progress and in the historical process seem to be fading, he [O. Paz] seems to me to be an important person. His experience, based on a half century of upheavals: no one knows what the future will look like; we have to be vigilant, careful, and skeptical, but we should also have hope. And for him, the most important thing is this: the highest value is not the future, but the present. "The future is not the time of love: what someone really wants, he wants now. He who constructs the house of future bliss is building the prison of the present." And the verdict on progress is this: "It has filled history with the miracles and monstrosities of technology, but it has emptied the lives of people; it has given us more things, not more being., ${ }^{, 74}$

(Unseld travel report, Paris, 5/20-5/22/1979, SUA)

Here, again, Unseld critiques the bourgeois belief in progress and the dichotomous relationship between "being and having," as Erich Fromm put it, within bourgeois value systems. In a volume of interviews published in 1996, Paz expresses that ambivalence this way:

There is a radical opposition between the values of modern society and poetry. The culture of capitalist society is fundamentally based on the morality of utility. And poetry is always an expense, a squandering. There is an incompatibility between bourgeois morality - which is the morality of thrift - and poetic morality, which is the morality of giving, of profligacy. ${ }^{75}$

(Peralta 2014 [1996]: 40)

Here we can recognize echoes of the radical Sartrean existentialism of the 1950s and, once again, Unseld's attempt to group Paz into his kaleidoscope of influential (European) thinkers and writers.

74 "Für mich ist er in unserer Zeit, wo der Fortschrittsglaube und Glaube an den historischen Prozess zu verdämmern scheint, eine wichtige Persönlichkeit. Seine Erfahrung aus einem halben Jahrhundert der Umstürze: niemand weiß, wie die Zukunft aussieht, wir müssen wachsam sein und aufpassen, skeptisch sein, aber wir sollten doch auch hoffen. Und für ihn ist das Wichtigste: der höchste Wert ist nicht die Zukunft, sondern die Gegenwart. 'Die Zukunft ist nicht die Zeit der Liebe: was der Mensch in Wahrheit will, das will er jetzt. Derjenige, der das Haus der künftigen Glückseligkeit konstruiert, errichtet das Gefängnis der Gegenwart.' Und das Urteil über den Fortschritt lautet: 'Er hat die Geschichte mit den Wundern und Monstren der Technik bevölkert, aber er hat das Leben der Menschen entvölkert, er hat uns mehr Dinge gegeben, nicht mehr Sein.”"

75 "hay una oposición radical entre los valores de la sociedad moderna y la poesía. La cultura de la sociedad capitalista está basada fundamentalmente en la moral de la utilidad. Y la poesía siempre es un gasto, un desperdicio. Hay incompatibilidad entre la moral burguesa - que es la moral del ahorro - y la moral poética, que es la moral del dar, del despilfarro.” 
Unseld's striving for legitimation is striking: he wants Latin American literature to be taken seriously enough that it will receive its justified inclusion in the canon of world literature: "I have to add that Latin American literature is a newcomer. It is the youngest of all Western literatures . . . . Latin America is a Far West" (Ich muß hinzufügen, daß die lateinamerikanische Literatur ein Neuankömmling ist. Sie ist die jüngste aller westlichen Literaturen . . . . Lateinamerika ist ein Ferner Westen; Unseld travel report, Paris, 5/20-5/22/1979, SUA). The "Far West" label serves to shift the established categories of affirmative Orientalism (which is also a world literary indicator) to a transatlantic sphere and, in the process, to adopt the established measures of value for the literary staging of the Other as the exotic. The ability to connect to the German tradition of cultural education (in the form of its highly canonical writers), coupled with leftist theorization, created a reception filter that was useful to the publishing house, because it pragmatically combined key topics of the "Suhrkamp culture": religiosity, ethics, and existentialism. In a lecture that he gave at Yale University on December 4, 1976, Paz put it this way:

Our literature is made out of relationships - clashes, influences, dialogues, polemics. Monologues between a few personalities and a few literary tendencies and styles that have crystallized into a work. These works have crossed national and ideological borders. The unity of fragmented Latin America can be found in its literature. ${ }^{76} \quad$ (Paz 2011 [1976])

\section{III.2.6 Isabel Allende: A “Stroke of Luck for Literature"}

Isabel Allende did not at first fit into this concept of a Latin American literature that, while shaped by conflicts, nevertheless itself created an important unity. She had little support as a writer in Latin America, and many critics opined that she was only serving Western literary tastes. But her work strongly shaped Suhrkamp's publishing program, albeit for completely different reasons than in the case of Octavio Paz. In the Suhrkamp Verlagsgeschichte 1950-1990 (The history of the Suhrkamp Publishing House, 1950-1990), Siegfried Unseld wrote the following about the publication of Isabel Allende's debut novel La casa de los espíritus (1982, published in German as Das Geisterhaus, 1984):

76 "Nuestra literatura está hecha de las relaciones - choques, influencias, diálogos, polémicas. Monólogos entre unas cuantas personalidades y unas cuantas tendencias literarias y estilos que han cristalizado en una obra. Esas obras han traspasado las fronteras nacionales y las ideológicas. La unidad de la desunida Hispanoamérica está en su literatura.” 
Isabel Allende's novel Das Geisterhaus [The House of the Spirits], translated from the Spanish by Anneliese Botond, appeared on March 12th. It is the first book by this author, the niece of the Chilean president Allende; after the September 11th, 1973 coup, she left Chile and now lives with her family in Venezuela as a journalist . . . . Nowhere was the success as great as in Germany . . . . The book was number 1 on the Spiegel's best seller list for many months. This "stroke of luck for literature" has now sold two million copies in Germany (as of June 1990). ${ }^{77}$

(1990: 163-64)

Isabel Allende (b. Lima 1942) is one of the most read authors in the world today, and certainly also the most commercially successful literary voice of the Spanish-speaking world. ${ }^{78}$ By her own account, she has published 23 books, which have been translated into 42 languages and have sold a total of 74 million copies. ${ }^{79}$ From a purely quantitative standpoint, the distribution of her work could only be compared with someone like Paulo Coelho, as Ilan Stavans remarked in the Times Literary Supplement in 2001 (cited in Heine 2002: 116). Over the course of Allende's career, she has received a large number of honorary doctorates and international literary prizes; at this point the number is more than 60 prizes, from more than 15 countries. ${ }^{80}$ Two of her novels have been made into movies. The first was La casa de los espiritus, made into the movie The House of the Spirits (1993), starring Meryl Streep, Jeremy Irons, and Glenn Close and directed by Bille August; the second was De amor y de sombra, filmed as Of Love and Shadows (1994), starring Antonio Banderas and Jennifer Connelly, directed by Betty Kaplan (Strausfeld 2012: 71).

77 “Am 12. März erscheint Isabel Allendes Roman Das Geisterhaus, aus dem Spanischen übersetzt von Anneliese Botond. Es ist das erste Buch dieser Autorin, der Nichte des chilenischen Präsidenten Allende, die nach dem Putsch vom 11. September 1973 Chile verließ und nun mit ihrer Familie als Journalistin in Venezuela lebt . . . . Nirgendwo war der Erfolg so groß wie in Deutschland . . . . Das Buch ist viele Monate lang die Nummer 1 der Bestsellerliste des ‘Spiegel.' Dieser 'Glücksfall für die Literatur' ist in Deutschland (Stand Juni 1990) mit zwei Millionen Exemplaren verbreitet."

Note that it's very hard to get reliable information on sales numbers for books because publishers, as business enterprises, are not required to be accountable to the public. In some cases the various figures that are given diverge considerably from each other.

78 An October 2009 article in the Latin American Herald Tribune calls Allende "the world's most widely read Spanish-language author" ("Isabel Allende" 2009).

79 As of March 2019. This information comes from the website of the Isabel Allende Foundation, the author's foundation to campaign for the rights of women and girls worldwide (https://s3-us-west-1.amazonaws.com/isabelallende.com/assets/bio/Bio_Isabel-en.pdf?kao das541ks). Suhrkamp talks about "more than 57 million copies" (https://www.suhrkamp.de/ isabel-allende_939.html), apparently based on Strausfeld's numbers (2012: 71), which were more than six years old at the time of this research.

80 These numbers also come from the website of the Isabel Allende Foundation (https://s3-us -west-1.amazonaws.com/isabelallende.com/assets/bio/Bio_Isabel-en.pdf?kaodas541ks). 
Even within this global success story, Allende's reception in Germany occupied an even more rarefied position, as Siegfried Unseld's account, quoted above, indicates; commercially, Allende's work was certainly a unique "stroke of luck" in publishing. The sales of the German translations that were published by Suhrkamp, especially of Das Geisterhaus (The House of the Spirits), can only be described as phenomenal, and played a notable role in fueling Allende's brilliant international career. In a 2002 interview, Jorge Heine listed sales figures for her first nine titles, broken down by language. ${ }^{81}$ These numbers show that of the approximately 32.5 million copies of these novels and stories in worldwide circulation, almost 8 million, in other words almost a quarter, are German translations (and therefore published by Suhrkamp). These numbers are also impressive because they make it clear that there were more German editions sold of these nine titles than editions in any other language, even more than in Spanish - in Spain and Latin America together (just under 6.6 million). This is particularly noticeable for Allende's debut novel La casa de los espíritus, which had sold more than 3 million copies in Germany just through 2002 (out of 10.8 million copies sold worldwide; Heine 2002: 120). ${ }^{82}$

How did this come about? The manuscript of La casa de los espiritus was rejected by a few Latin American publishing houses to begin with, so Allende sent it to the Spanish agent Carmen Balcells, who also, famously, represented Gabriel García Márquez, among others. The novel was finally published by the Spanish publisher Plaza \& Janés, in 1982, and won the Mazatlán Prize that same year. Allende came to the attention of Michi Strausfeld, who at that point was working as an independent literary talent scout for Suhrkamp, at the book launch in Barcelona. Strausfeld recommended the book to Suhrkamp, which

81 Heine (2002: 120) gives figures for the following countries or linguistic regions: Germany (we can assume that he means the entire German-speaking area, in other words also Austria and Switzerland), Brazil, Denmark, Spain/Latin America, Finland, France/Canada, Greece, the Netherlands, Iceland, Israel, Italy, Japan, Norway, Portugal, Sweden, Turkey, and the United States/Great Britain.

82 In 2007, Sperschneider (2007: 108) also mentioned the fact that La casa de los espíritus had sold 3 million copies in the German translation, as Das Geisterhaus. As early as 1987, Gottfried Honnefelder, then managing director at Surhkamp, spoke of 500,000 copies sold in talking to Die Zeit (Greiner 1987). Three years later, as mentioned above, Unseld then gave the number of 2 million (Suhrkamp Verlagsgeschichte 1990: 163-64). As for the novel's circulation worldwide, Suhrkamp's website gives the unbelievable figure of 51 million copies sold (https://www.suhr kamp.de/isabel-allende/das-geisterhaus_942.html). That must surely be a mistake; Suhrkamp must have taken an old number for total sales of Allende's books (the number that is still given on the writer's German Wikipedia page, https://de.wikipedia.org/wiki/Isabel_Allende), and wrongly assigned it to the first novel alone. 
then acquired the German rights and had Anneliese Botond translate the novel into German. In 1984, it was published with the title Das Geisterhaus (Brown 1994: 37). Botond won the Johann-Heinrich-Voß Prize for her translation, a prize that is given by the German Academy for Language and Literature for "outstanding achievements in translation." In 1985, Das Geisterhaus shot to number 1 on the German bestseller list, and for the entire year it was always among the top ten (Gerling 2007: 74). At first, Suhrkamp advertised Allende in the "young author" category (Strausfeld 2007: 165). Her next three books, two novels and a short story collection that came out in rapid succession, also landed on the German bestseller list: Von Liebe und Schatten (1986; original Spanish title De amor y de sombra, 1984 [Of Love and Shadows]), Eva Luna (1988; original Spanish title Eva Luna, 1987), and Geschichten der Eva Luna (1990; original Spanish title Cuentos de Eva Luna, 1989 [Stories of Eva Luna]; Brown 1994: 60). And even though nothing approaching Das Geisterhaus's impressive sales figures was ever again attained, Isabel Allende's novels remain reliably among the Spiegel's top ten bestseller list to this day. ${ }^{83}$ Their enormous commercial success meant that the time that elapsed between the original publication of her works in Spanish and the appearance of their German translations $^{84}$ became shorter and shorter, until they were appearing at almost the same time, whereas the comparable time lag for less successful writers is much larger, often as much as a few years (Sperschneider 2007: 108).

What are the significant reception patterns with respect to Isabel Allende's literature in this context? In Latin America, literary critics have accused the author of catering only to Western literary tastes, of turning away from Latin America and belonging to the United States in her heart, and have claimed that she will use any means to market her books - people especially resent her selfdesignation as a political exile. ${ }^{85}$ This background is necessary to explain why, in spite of her great international literary renown, the author was never officially recognized in Chile, her country of origin, until 2010, when she won the National Prize for Literature there (Strausfeld 2012: 71). In the English-speaking

83 See most recently Ein unvergänglicher Sommer (Más allá del invierno [In the Midst of Winter]), at number 4 in the summer of 2018.

84 While Anneliese Botond translated Allende's debut novel, Dagmar Ploetz took over the translation of De amor y de sombra into German. Unlike her predecessor, Ploetz was heavily criticized for her translation (see Brown 1994: 39). The third novel, Eva Luna, was translated by Lieselotte Kolanoske, who remained Isabel Allende's German voice for 15 years, until Svenja Becker took over that role in 2003.

85 Cf. Heine (2002: 116), who cites a variety of critical voices. 
world, where her books are also best selling hits, there are mixed reactions to the phenomenon that is Isabel Allende. Some people reject her novels as unconvincing imitations of the great classics of magical realism; in 2001, for example, Ilan Stavans wrote in the Times Literary Supplement that Allende was the first woman to be taken seriously in the context of the Latin American Boom, ${ }^{86}$ but that she had also ushered in the end of that literary experiment, replacing it with pure entertainment. Allende, he wrote, had carried to the extreme the transformation of literature into a mass-market consumer good (cited in Heine 2002: 116). But there are opposing voices as well; Philip Swanson, for instance, saw in the critiques of La casa de los espiritus an overwhelming set of expectations, focused primarily on politics and complexity. These always involve a "radical leftist politics preferably expressed through a radically subversive narrative form" (Swanson 2003: 57). But Swanson himself sees the great strength of the novel precisely in the fact that it breaks with the tendency of Latin American literature towards complexity and the unknown and brings so-called magical realism back into a more communicative form.

On the whole, German-language newspapers' culture sections were more generous to Das Geisterhaus and the following novels, although criticisms of aspects of Allende's work that are considered shallow or commercial keep coming up. Eighteen years after the publication of Das Geisterhaus, Martin Ebel looked back on Allende's oeuvre in the pages of the Frankfurter Allgemeine Zeitung as a "soft, comfortable version of Latin American modernism: Isabel Allende played the female García Márquez, without narrative risk, without the power, breath, and rage of the Nobel Prize winner, without his edges and ambitions. What she offered was what you could call literary cuddle sex" (kommode[] und softe[] Variante lateinamerikanischer Moderne: Isabel Allende gab den weiblichen García Márquez, ohne erzählerisches Risiko, ohne Kraft, Atem und Furor des Nobelpreisträgers, ohne seine Härten und Ansprüche. Was sie bot, war sozusagen literarischer Kuschelsex; Ebel 2002: 40). Another reviewer wrote about Geschichten der Eva Luna: "The exotic, perfumed magic of a narrative art that chased away Nordic gloom in such an entertaining way seemed all too seductive" (Allzu verführerisch erschien der exotisch parfümierte Zauber einer Erzählkunst, die den nordischen Trübsinn auf so unterhaltsame Weise vertrieb; Brown 1994: 123). Eva Luna is called, among other things, an "exotic fairy tale" (exotisches Märchen, 121) that "colors the South American ambience . . . with thick dabs of sweat, semen, blood” (mit dicken Tupfen aus Schweiß, Sperma, Blut . . .

86 This is how literary critics classified her; in literary scholarship, however, Isabel Allende is not considered part of the Latin American literary Boom. 
[das] südamerikanische Ambiente koloriert, 126). Here we can see very clearly a crucial reception framework that focuses on an exuberant, sensually based exoticism that clearly played an enormous role in making Allende's work such a favorite with the public. Suhrkamp's marketing strategy also pointed in that direction, praising Das Geisterhaus on the one hand as one "of the most successful novels of world literature" and on the other hand advertising it with an appeal to exoticism and sensual promises: "In a world inhabited by spirits and full of secrets and dark suspicions, Isabel Allende produces flesh-and-blood figures driven by their convictions and passions" (In einer von Geistern bewohnten Welt, voller Geheimnisse und dunkler Ahnungen lässt Isabel Allende Figuren aus Fleisch und Blut auftreten, die von ihren Überzeugungen und Leidenschaften getrieben sind). ${ }^{87}$ In his review of Portrait in Sepia, Martin Ebel puts the role that Suhrkamp's Latin America program assigned to Isabel Allende's novels in a nutshell:

Isabel Allende is not exactly a jewel in Suhrkamp Verlag's impressive line-up of international writers - but on their balance sheet, she certainly is. There are colleagues for whom it is the other way around, and both of those should be present and ought to be allowed in a publisher's calculated mix.

(2002: 40)

\section{III.2.7 Excursion: North American Literature at Suhrkamp: The Case of William Faulkner}

Writers from the United States, none of whom found success on the level of the Latin American writers, were mostly included in the "Bibliothek Suhrkamp" book series, which represented modern classics, such as those of William Faulkner, Sherwood Anderson, Gertrude Stein, and Truman Capote. It is worth taking a look at William Faulkner here, if only because most of the writers of the Latin American Boom say that they could not have written without him. Édouard Glissant, the Martiniquan writer and cultural theorist who died in 2011, dedicated a 300-page literary essay to Faulkner entitled Faulkner, Mississippi. If we want to understand the strong reception that Faulkner's work received from Latin American writers, we have to take into consideration the omnipresent hemispheric dimension of the Americas in that work. Marcel Vejmelka has very convincingly pointed out the resulting cultural-theoretical implications: Yoknapatawpha County, the fictitious county that Faulkner built up around the city of Jefferson over the course of numerous novels and stories, contains a multitude of historical dimensions that connect it with other areas of the American

87 https://www.suhrkamp.de/isabel-allende/das-geisterhaus_942.html. 
continent. ${ }^{88}$ The "essential rationales of the colonial and postcolonial configuration" (Grundlogiken der kolonialen und postkolonialen Konfiguration) of his culture that become visible in Yoknapatawpha positioned Faulkner's southern United States in complex interrelations with other regions of "plantation America," characterized by the simultaneously colonial and capitalist machinery of the plantation economy (Vejmelka 2009: 157-58). The historical experience of the plantation economy - of the white landowners and African slaves, as well as of the Deep South conquered by the modern North of the United States, of the suffering of a region that was forcibly incorporated into the modern national project of the (northern) United States and internally colonized but that also knows of the guilt it carries as a slaver society - this historical experience that Faulkner displays creates a relational logic that makes it possible to look at Yoknapatawpha County from beyond its regional specifics and to analyze it with regard to fundamental questions of the cultural configuration and identities of the Americas. Thus, Faulkner's work positions itself on the border within the Americas that is accepted, asserted, questioned, or problematized, respectively, from both the North and the South (158).

It makes sense that Édouard Glissant would gratefully build on this material: in Faulkner, Mississippi, his literary travelogue, he brings to light the constellation of "master's house and slave hut" that the anthropologist Gilberto Freyre investigated in northeastern Brazil in 1933, making reference at the same time to Faulkner's estate near Oxford - from one South to another South (Vejmelka 2009: 172-73). Vejmelka shows the extent to which Glissant maps this "spatial miniature of Brazil” (räumliche Miniatur Brasiliens) - of its economic, social, and in particular ethnic development - onto the plantations of the South of the United States, where Faulkner's life and work are rooted (163). It is precisely in the temporal balancing act of these hemispheric constructions of America between Faulkner and Glissant that the unity of the Americas becomes evident, in both the act of writing and the act of reading. This cultural-theoretical dimension, which has been underestimated in Latin American studies, is also reflected in the reception in Germany and thus also has consequences for the worldwide processes of canonization. What, then, is Suhrkamp's specific position?

Not much of Faulkner's work was published in German. Suhrkamp only published his novel Als ich im Sterben lag (1961; As I Lay Dying), the short story Der Bär (1953; The Bear), and the novel Wilde Palmen (1957; The Wild Palms); but because they didn't appear until after he had already won the Nobel Prize,

88 For these remarks on Faulkner I draw directly from Marcel Vejmelka's valuable work (2009: here p. 157). 
the publisher cannot pride itself on having done any pioneering work in publishing him. As for Glissant, he has still only been published by the small, vanguard Heidelberg publishing house Das Wunderhorn. This non-publication can only make us ask, at this point, how, in the context of an investigation of the history of the publishing house, a history of exclusions could be written, which would be highly relevant from the point of view of cultural studies.

\section{III.2.8 Elena Poniatowska: Belated Interest at Suhrkamp}

Some of the works of the Mexican writer Elena Poniatowska, who was, among other things, a winner of the Cervantes Prize, also fell through the world literary selection grid of the international publishers and gatekeepers, as already mentioned in section II.2. This forces us to ask: while Suhrkamp published four of the author's works over the years, why did they not publish her work earlier and not publish more of it? And above all, why did they not publish her discoursedefining works? The SUA files in Marbach show that as early as 1971, Mauricio Schoijet, a literary agent who worked for Poniatowska's publisher Era in Mexico, had written to Hans Magnus Enzensberger to recommend to Suhrkamp several of the books that Era had published, including, first of all and most importantly, $L a$ noche de Tlatelolco, at that time still a new classic of testimonial literature, about the bloody suppression of the student protests on October 2, 1968, in Mexico City. Schoijet called the book a "great journalistic collage" (große journalistische Collage) and also emphasized the unusual sales success of this literary-journalistic chronicle in Mexico, estimating that 50,000 copies had been sold. At the same time, he not only reflected on the difficulties to be expected in translating the book into German, given the many local references and the heavily Mexicantinged Spanish, he also recommended a qualified and proven translator, who herself lived in Mexico City and would be able to translate the work in dialogue with the author. In addition, the agent offered to provide an annotated version of the text tailored to the German reading public, and had even organized a writer for a potential afterword on the political situation in Mexico (letter from M. Schoijet to H. M. Enzensberger, 11/30/1971, SUA).

Suhrkamp decided against the publication. At that time, its Latin America program was almost exclusively publishing essays on the leftist movements and political upheavals in Latin America, such as Peru 1965. Aufzeichnungen eines Guerilla-Aufstands (Peru 1965: Notes on a Guerrilla Experience; Héctor Béjar Rivera, 1970); Venezuela. Die Gewalt als Voraussetzung der Freiheit (Venezuela: Violence as the condition of freedom; Orlando Araujo, 1971); and Guatemala. Unterentwicklung und Gewalt (Guatemala: Underdevelopment and 
violence; Juan Maestre Alfonso, 1971). The first book of Darcy Ribeiro's that Suhrkamp published, Der zivilisatorische Prozeß (The Civilizational Process), also came out in 1971. In terms of content, then, Poniatowska's documentary work would have fit in perfectly with Suhrkamp's selection criteria for works by Latin American writers. Nor should the collage-like construction of La noche de Tlalelco have been perceived as particularly problematic or uninteresting, given that Suhrkamp absolutely saw itself as a progressive publisher in literary terms. However, there was not one single woman among Suhrkamp's Latin American authors at that time, in the early 1970s. This did not change until 1978, when Suhrkamp published a book by the Brazilian Rachel de Queiroz, followed three years later by Clarice Lispector (1981, 1982, and 1983). The first female Spanish-language Latin American writer that Suhrkamp published in its Latin America program was Isabel Allende, in 1984.

As for Elena Poniatowska, it was not until the early 1980s that Suhrkamp began to be interested in her work. In late 1980 and early 1981, Michi Strausfeld, who was still significantly responsible for Suhrkamp's Latin America program, wrote evaluations of two of Poniatowska's works: first, on Hasta no verte, Jesús mío (Until We Meet Again/Here's To You, Jesusa!), a testimonial novel about the unusual life of a simple Mexican woman, based on interviews; and second, on Fuerte es el silencio (Silence is strong), a volume of five journalistic reports that had just appeared. Strausfeld's conclusion about Hasta no verte, Jesús mío was as follows:

A very well-written biographical novel, with which the author has also made a name for herself as one of the few good female writers in Latin America . . . . Given that these "life stories" clearly resonate in Germany, I would recommend publishing this book - it is one of the best of its kind. ${ }^{89}$

(Evaluation by M. Strausfeld, 12/18/1980, SUA)

Strausfeld leaves no doubt about the literary quality of the book, ending her evaluation with a superlative: as a journalist, Poniatowska counts as "the best" in Latin America. But this novel was apparently also not a good enough fit for the Suhrkamp Verlag's reception patterns. Instead of being published by Suhrkamp, this second major work of Poniatowska's, to which she owed her international reputation and which was also translated into English, French, and

89 "Eine sehr gut geschriebene Roman-Biographie, mit der die Autorin sich zugleich als eine der wenigen guten weiblichen Schriftstellerinnen Lateinamerikas profiliert hat . . . . Da diese 'Lebensberichte' offensichtlich gutes Echo in Deutschland finden, würde ich die Publikation des Buches empfehlen - es zählt zu den besten seiner Gattung.” 
Italian, appeared in German in 1982 as a publication of the small publisher Lamuv Verlag, with the title Allem zum Trotz . . . : das Leben der Jesusa. The first thing that Suhrkamp published of hers was Stark ist das Schweigen. 4 Reportagen aus Mexiko, a translation of four of the five reports in Fuerte es el silencio (Ediciones Era 1980), and that was not until 1987. In her report in early 1981, Michi Strausfeld had already been downright enthusiastic:

Every topic is captivatingly written; literary reportages that piece together, from the many carefully researched details, stories that hauntingly and graphically show us Mexican reality. The author has truly loaned her voice to those people who cannot speak themselves: and she writes in such a way that you will never forget the topic . . . . I urgently recommend the publication of these reports! ${ }^{90} \quad$ (Evaluation by M. Strausfeld, 01/19/1981, SUA)

In 1989, two years after Stark ist das Schweigen, the decision was made at Suhrkamp to publish another work, out of Poniatowska's already existing oeuvre, for the German market. However, the publisher did not choose the chronicle of the Tlatelolco massacre, which would have been a perfect segue from the previous publication and also featured an event that was iconic for the leftist movement; the period of political utopias connected to Latin America was long past its prime. Instead, Suhrkamp published Lieber Diego (original Spanish title Querido Diego, te abraza Quiela, Ediciones Era 1978 [Dear Diego]), an epistolary novel that dealt with Diego Rivera, another Mexican icon, and that was, apart from that, more anchored in private, emotional themes. The next books to appear from Suhrkamp were Tinissima. Der Lebensroman der Tina Modotti (1996; original Spanish title Tinísima, Ediciones Era 1992 [published in English as Tinisima]) and Frau des Windes (which appeared in Suhrkamp's Insel Verlag imprint in 2012; original Spanish title Leonora, Seix Barral 2011 [also published in English as Leonora]). Poniatowska, a politically and socially engaged writer, has played a rather subordinate role in the publisher's programming choices; the predominant reception pattern, especially for the last three publications, can be considered exoticizations, combined with a decidedly female perspective. Neither the volume of reportages nor the novels, however, are currently listed as available on Suhrkamp's website (as of April 2019).

90 "Jedes Thema ist mitreissend geschrieben; literarische Reportagen, die aus den vielen, sorgfältig recherchierten Einzelheiten Geschichten zusammensetzen, die die mexikanische Realität eindringlich und plastisch vor Augen führt. Die Autorin hat wirklich ihre Stimme jenen Menschen geliehen, die nicht selber reden können: und sie schreibt so, dass man das Thema nicht wieder vergisst . . . . Ich empfehle die Publikation dieser Reportagen ganz dringlich!" 


\section{III.2.9 The Latin America Program, Part II: The Post-Success Phase, 2000-2017. After Exoticism}

After the Boom, how did Latin American literatures develop before they arrived in Germany? As we have already seen (in section II.1), there was a conspicuous departure from specifically Latin American topics, in some cases already here and there in the late works of the successful Boom writers, but then very distinctly among the young generation of writers starting in the early 1990s. What was Suhrkamp's reaction? While the publisher's Latin America program continued to flourish in the 1980s and 1990s, from 2000 onward it began a significant stagnation. ${ }^{91}$ From 2001 to 2017, the program included “only” 105 new titles. By comparison, in the 17 years before the turn of the millennium (from 1984 to 2000), that number had been 164 publications. If we compare the annual statistical mean of the two time periods, the number of annual publications from Latin America was cut almost in half, from ten titles a year before the turn of the millennium to six titles a year after it.

The jacket copy (which is of necessity market-oriented) on a novel from Latin America that appeared in Germany in 2011 can give us some insight into Suhrkamp's publication strategies. The novel, 35 muertos (German title 35 Tote), is by Sergio Álvarez (b. 1965), from Colombia, and the promotional copy reads as follows:

After One Hundred Years of Solitude - the great Colombian novel. In this country, anyone who has never killed someone has no future. Breathtaking, harrowing, captivating. With 35 muertos [35 dead], Sergio Álvarez offers a powerful response to García Márquez's One Hundred Years of Solitude. ${ }^{92}$

To what extent, then, are the literary tendencies of the younger generation compatible with the erstwhile aspirations to the "world literature" stamp of approval? With respect to the paradigm shift within literary and cultural studies from "world literature" to "literatures of the world" (see section III.1), Suhrkamp has responded in accordance with its earlier aspirations to be in dialogue with the current tendencies of the intellectual avant-garde and to have a significant determining voice in the debates through its choice of authors. Thus, for

91 I address this phase of Suhrkamp's Latin America program, among other things, in Müller (2014a, 2015a, 2015b).

92 "Nach Hundert Jahre Einsamkeit - der große Kolumbien-Roman. Wer in diesem Land niemanden getötet hat, der hat keine Zukunft. Atemberaubend, erschütternd, fesselnd. Dem magischen Realismus von García Márquez' Hundert Jahre Einsamkeit setzt Sergio Álvarez mit 35 Tote einen kraftvollen Roman entgegen.” 
example, the publisher's website promotes the Suhrkamp author Nedim Gürsel, from eastern Turkey, who was the Samuel Fischer Guest Professor for Literature: Literatures of the World at the Free University of Berlin in 2011-12. Suhrkamp takes on the demands of the title of this professorship in an affirmative fashion, emphasizing the publisher's intention to "promote a critical reflection on the literatures of the world" (eine kritische Reflexion über die Literaturen der Welt zu fördern). ${ }^{93}$ After all, this refers to texts that situate themselves within global relationships and in which cultural positionings are reflected or in fact developed.

Given the conditions of transnational lives and the privileged situation of non-settled literatures, there are of course literary texts, particularly in Latin America, that make such readings possible. An example is one of the most recent novels by the longtime Suhrkamp author Mario Vargas Llosa, El sueño del celta (The Dream of the Celt), published in 2010 by the prestigious Spanish publisher Alfaguara. In the book there are transnational movements between three regions of the world: Ireland, Congo, and the Brazilian Amazon. And yet Suhrkamp was not particularly interested at first: During the Frankfurt Book Fair, in October of 2010, when it was announced that Mario Vargas Llosa had been awarded the Nobel Prize in Literature (see Meyer-Krentler 2010), the Suhrkamp Verlag immediately made much of its position as Vargas Llosa's illustrious German publisher, but shortly thereafter it came out that only four weeks earlier, in negotiations for rights to publish the German edition of El sueño del celta, Suhrkamp had passed on it, and now Rowohlt had acquired the rights. In the context of the Nobel Prize, the decision not to publish the most recent novel became a publishing scandal that dragged on for several months, until Rowohlt finally renounced the rights and the novel was able to be published by Suhrkamp after all, under the title Der Traum des Kelten. This was celebrated in the fall of 2011 with an inaugural event at the Haus der Berliner Festspiele. The opening lecture by Ulla Berkéwicz, the head of Suhrkamp at that time, hailed the novel as Vargas Llosa's return to his original storytelling, emphasizing the otherness of what was specifically Peruvian in the book as well as its magical narrative style.

93 http://www.suhrkamp.de/news/samuel_fischer_gastprofessur_fuer_literatur_1702.html. 


\section{III.2.10 Samanta Schweblin: Most Recent Trends in Publishing}

In Suhrkamp's Latin America Program, Samanta Schweblin represents the most recent tendencies in publishing policies, which assert a global relevance, in the sense of a universalist aspiration, for the current literature of the subcontinent, but without any particular reference to specifically Latin American discourses. Schweblin, whom Mario Vargas Llosa called "one of the most promising voices of modern Spanish-language literature,"94 was born in Buenos Aires in 1978. She has published three short story collections and two novels so far, which have been translated into 25 languages (Literaturport). Her short story collections El núcleo del disturbio (2002; The nucleus of the disturbance), Pájaros en la boca (2008; Mouthful of Birds), and Siete casas vacías (2015; Seven empty houses) have won the National Arts Foundation Prize (Argentina), the Casa de las Américas Prize (Cuba), the Juan Rulfo Prize (France), and the highly endowed Ribero del Duero Short Story Prize (Spain). In addition, the English translation (Fever Dream) of her first novel, Distancia de Rescate (2014), was shortlisted for the 2017 Man Booker International Prize (UK) and won the 2018 Shirley Jackson Award (USA).

In the international press, the reviews did not hold back with their superlatives: El País called Schweblin a "master of the short form" and considered her to be in the same league as Jorge Luis Borges, Julio Cortázar, and Juan Rulfo; ${ }^{95}$ La Nación celebrated Fever Dream as a "decisive literary event"; 96 and Clarín simply wrote that Schweblin was "the most prestigious, most awardwinning, and most translated Argentine story-writer of the moment" (la narradora argentina más prestigiosa, premiada y traducida del momento, Fernández 2018). Reviewing Schweblin's debut novel Fever Dream, the Economist wrote that it "wraps contemporary nightmares, both private and public, into a compact, but explosive, package" ("Samanta Schweblin” 2017). In China, where Schweblin spent two months as part of the Shanghai Writers' Program, ${ }^{97}$ and where the Shanghai publishing house 99reader translated her collection Pájaros en la boca in 2013, her literature is received as enthusiastically as it is in the Western world. Many of the discussions of Schweblin's writing emphasize her use of imagery. Thus Daniel Alarcón writes that like a poet, she communicates through images - and the Chinese novelist A Yi goes so far as to compare

94 Quoted in https://www.suhrkamp.de/autoren/samanta_schweblin_8074.html.

95 Quoted in https://www.suhrkamp.de/buecher/sieben_leere_haeuser-samanta_schweblin_ 42804.html.

96 See https://www.suhrkamp.de/buecher/das_gift-samanta_schweblin_42503.html.

97 See https://de.wikipedia.org/wiki/Samanta_Schweblin. 
Schweblin's stories to Chinese paintings, seeing parallels in how both art forms open up a space for the reader's imagination (Xi 2013).

It was not until 2010 that the German-language reading public was able to discover Samanta Schweblin. On the occasion of Argentina's appearance as guest of honor at the 2010 Frankfurt Book Fair, Suhrkamp commissioned a translation of Schweblin's second short story collection, Pájaros en la boca (Mouthful of Birds), with financial support from the Argentine translation fund PROSUR. Since then, in addition to that first translation (by Angelica Ammar), published in German as Die Wahrheit über die Zukunft, Suhrkamp has also published Das Gift (2015, translated by Marianne Gareis; original Spanish title Distancia de Rescate, 2014 [Fever Dream]) and Sieben leere Häuser (2018, also translated by Marianne Gareis; original Spanish title Siete casas vacías, 2015 [Seven empty houses]). If we look at the book presentations and international press reviews that Suhrkamp presents on its home page to advertise its publications of Schweblin's books, there is a noticeable focus in the vast majority of the reviews on Schweblin's particular writing style. Thus, for example, Suhrkamp emphasizes her "masterfully laconic" (meisterhaft lakonischen) ${ }^{98}$ style and the fact that she creates her "own, wondrous narrative cosmos" (einen eigenen, wundersamen Erzählkosmos). ${ }^{99}$ Le Monde, in turn, praises the author's "unique way of looking at things" (einzigartigen Blick auf die Dinge, in Suhrkamp's translation). ${ }^{100}$ Until recently, there was always an obligatory reference to their origins in discussions of Latin American writers, but that appears no longer to be the primary reception model at Suhrkamp: neither in the form of a literary genealogy, as was done for Vargas Llosa, whose novel El sueño del celta was (mistakenly) praised, as recently as 2011, as being a continuation of magical realism; nor as a revolt or struggle against the Boom-generation forefathers, as in the case of the Crack movement, McOndo, or, specifically with respect to Suhrkamp, the case of Sergio Álvarez, whose literary relevance was noted on the jacket copy of 35 Tote as consisting of an alternative to García Márquez's One Hundred Years of Solitude (see section III.2.9). When the reviews do praise Schweblin by discussing her "linguistic precision" (sprachliche Präzision) as something that "is very rarely found in Latin American writers" (wie man sie nur

98 https://www.suhrkamp.de/buecher/sieben_leere_haeuser-samanta_schweblin_42804. html.

99 https://www.suhrkamp.de/buecher/die_wahrheit_ueber_die_zukunft-samanta_schwe blin_42142.html.

100 Cited in https://www.suhrkamp.de/buecher/sieben_leere_haeuser-samanta_schweblin_ 42804.html. 
ganz selten bei lateinamerikanischen Autoren antrifft), ${ }^{101}$ or when the notorious buzzwords of the Latin American Boom are lined up again for her ("in Samanta Schweblin's Argentina, the magical becomes political”; in Samanta Schweblins Argentinien wird das Magische politisch, Heidemann 2015), it seems strangely disjointed and almost anachronistic, an outdated reflex.

As far as literary or aesthetic affinities go, the book reviews and writer profiles certainly also contain well-founded references to an Argentine literary tradition, especially to the neofantasticism of such writers as Adolfo Bioy Casares, Julio Cortázar, and Jorge Luis Borges (see for example Halter 2015; A. Müller 2010). Of course, this also has to do with the genre of the short story, which is one of Schweblin's preferred artistic forms and also has a strong tradition in Argentina. The author herself, however, only accepts this attribution to a limited degree. For one thing, the literary role models that she herself names tend to be North American writers, such as Flannery O'Connor, John Cheever, Raymond Carver, and J. D. Salinger (Schweblin 2010; Quiroga 2015), and for another, she stresses how important it is to her that her literature remains suspended between the real and the unreal: "Argentine literary criticism sees me as being in the tradition of Jorge Luis Borges or Julio Cortázar. That is of course an honor; I admire their work. But I don't believe that my stories can be considered fantastic literature. Because they could all happen exactly that way!" (Klobusiczky 2012). The more appropriate references might be those to Franz Kafka or to David Lynch's hallucinatory visual worlds (cf. Person 2010; Halter 2015; Heidemann 2015). What we see in Schweblin's work are by no means regionally specific forms, such as the "magical," but in fact quite the opposite, namely topics and perspectives that are at the same time both radically individual and universally valid, as the author herself puts it in an interview, with respect to Distancia de rescate: "it is a novel written in the first person, the very absolute first person, from beginning to end. It takes place inside a woman's head, and everything is personal. And when everything is personal, it becomes universal" (es una novela escrita desde la primera, primerísima persona, de punta a punta. Pasa en la cabeza de una mujer, y todo es personal. Y cuando todo es personal, se vuelve universal; Benavides 2018).

101 Tobias Wenzel, from the WDR, cited in https://www.suhrkamp.de/buecher/sieben_leere_ haeuser-samanta_schweblin_42804.html. The entire article can be found at: https://www1. wdr.de/kultur/buecher/sieben-leere-haeuser-104.html. 


\section{III.2.11 Concepts of World Literature in the Publishing World: Current Perspectives}

We see, therefore, that to this day, the literatures of America are sorted through the dominant reception filter of "world literature" at Suhrkamp. The Goethean provenance of the concept plays at least a latent role in this process. The division of the publishing house into regionally distinct sectors is symptomatic. The great successes among Latin American novels corresponded to these European criteria of world literature. But from the moment that the writers began to disregard those criteria, they lost recognition. The decline in the Latin American Boom at Suhrkamp is a response to the failure to comply with Eurocentrically defined rules of world literature, in which both universalism and exoticism are inherent: it was Latin American literatures, in particular, that gained recognition through the staging of an exoticizing discourse of identity, which defined itself in contrast to a European self-understanding. At the moment when the novels ceased to focus on the staging of what was specifically Latin American, they lost their attractiveness in terms of world literature and now no longer have the central importance within Suhrkamp's publishing program that used to be accorded to them.

As we have seen, the concept of "literatures of the world" has become increasingly prevalent in literary studies and in the literary trade in the last twenty years, and some publishers and cultural institutions have also taken up this term. At first glance, it would seem as though Suhrkamp had also jumped on this bandwagon, as implicitly as with the concept of "world literature"; but when we look more closely, it becomes clear that it really only seems that way. The contradiction between the boldly expressed claims on the website, on the one hand, and the Vargas Llosa case in 2010, on the other, speaks for itself. The gaps in the system - such as the non-inclusion of William Faulkner and Édouard Glissant, as well as of certain works of Elena Poniatowska's - are particularly instructive in understanding the policies of the publisher, and allow us to draw a chronological line from the beginning of the Suhrkamp era, in the 1950s, to today. The case of Samanta Schweblin, however, does show that there is currently a break being made from the longstanding expectations that were placed on Latin American literatures and the exoticist and essentialist elements that were supposedly inherent in them. 